\title{
Translating Songs in Shakespearean Drama: Adaptation or Appropriation?
}

\section{Shaymaa Adham Basheer}

Assistant Professor of English Department, faculty of Arts,South Valley University, Qena, Egypt

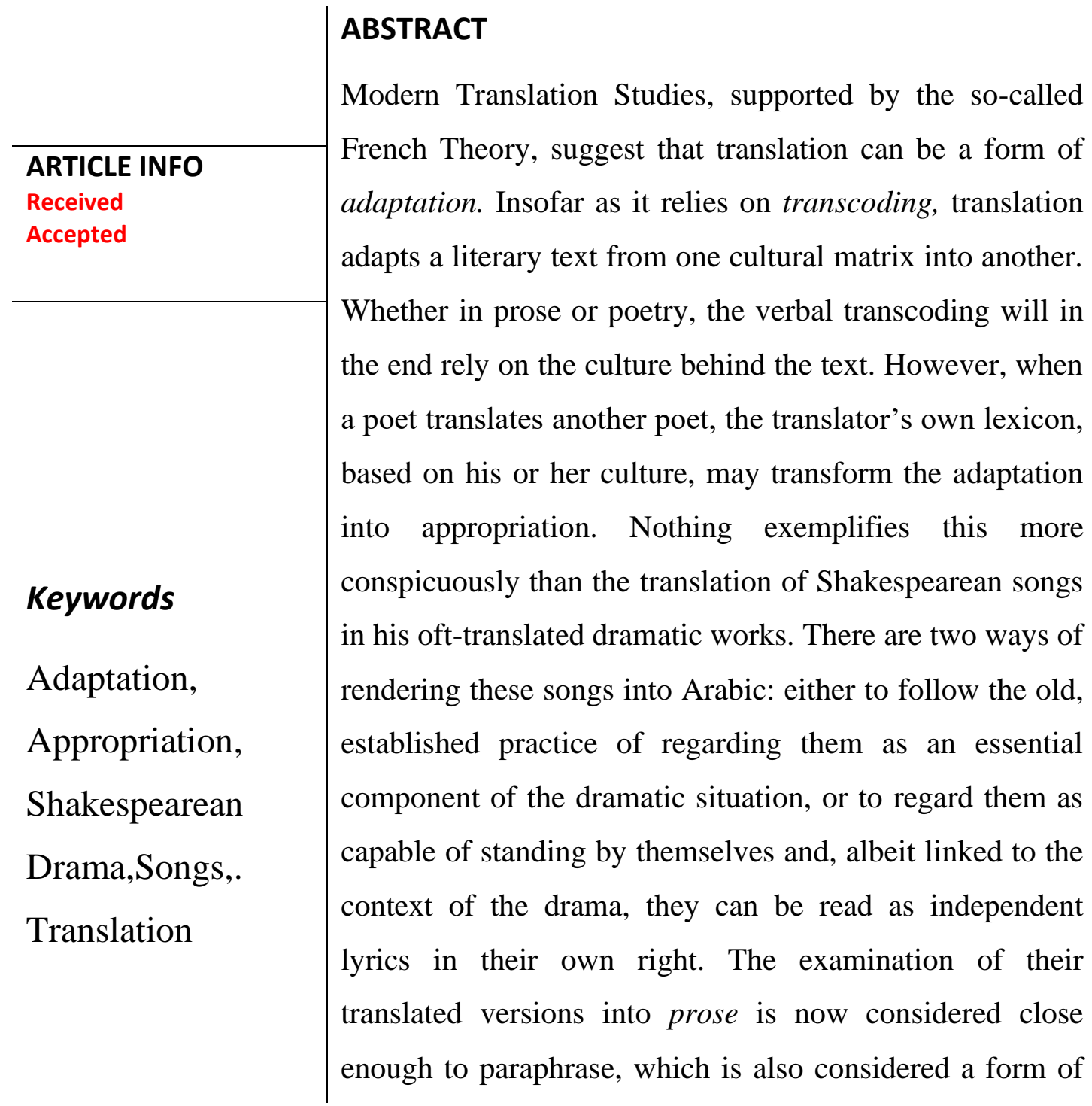


adaptation. However, it is in poetry that one can perceive the change of adaptation into appropriation. Translations by Mutran, Al-Wakeel, Enani and Badawi show that there has been a consistent tendency of adapting the songs to the cultural milieu of the translator, with more appropriation noted in the work of the early $20^{\text {th }}$ century poet, Khalil Mutran, than in more recent translations. Recent translators increasingly think of the songs as part and parcel of the Shakespearean text.

\section{Introduction}

Critics have written more than enough about the function of songs in Shakespearean drama. They tend to represent two viewpoints, not necessarily as irreconcilable as they seem to be. The first is to regard songs as part and parcel of the play's action, or plot, the second as entertainment, being ironic or otherwise funny, designed to relieve the tension when a situation becomes too stressful for the audience to easily tolerate. The former view is therefore text-oriented, the second audience-oriented. Represented by the classically-trained scholars of the $20^{\text {th }}$ century, Charles T. Pooler (1916), John Dover Wilson (1926) and John Russell Brown, (1964), the former insists that the songs, either by professional singers or by the Fool or Clown, comment on the scene in which they occur or look forward to a future event. This view survives in the work of Drakakis, editor of the Arden Merchant of 
Venice (2010-2018). The other view is more modern, as shown in the writings of Richard Halpern (1991) and Frank Kermode (2000).

As these songs are all in verse, their Arabic translations, if in verse, should tend to support one of these views, though occasionally combining them. However, if translated into prose they will appear more like a "paraphrase" than an "imitation", in terms of Dryden's translation theory (Preface to Ovid's translation, 1608). As paraphrase, the Arabic text would support the earlier view; but if in verse, they could support either or both views.

Naturally, experienced Arabic translators opt, though implicitly, for the second, but still allowing for the more recent view to be perceived. However, if the translator's departure from the so-called source text is conspicuous, the modern view may regard it as adaptation. Linda Hutcheon defines adaptation as closest to Dryden's imitation, with the possibility that the adaptation may be shown to have appropriated Shakespeare's text (A Theory of Adaptation, 2006). In the Preface to the second edition of that book (2013), she tells us that in the interim "new collections of essays have broadened the range of both the theory and practice of adaptation studies to include indigenization across cultures as well as translations across languages (in Laurence Raw, ed. Translation, Adaptation and Transformation [2011]". She cites other works such as Rachel Carroll, ed. Adaptation in Contemporary Culture: Textual Infidelities, 2009, and Tricia Hopton, 
Adam Atkinson, Jane Stadler, and Peter Mitchell ed. Pockets of Change: Adaptation and Cultural Transition, 2011, (cf. pp. 88 ff.)

\section{A New Outlook}

In her Preface to the first edition of the book, Hutcheon builds up a cogent argument for adaptation, criticizing the "constant critical denigration of the general phenomenon of adaptation" in all its forms. (p. xiii-xiv). She tells us that from her experience she has learnt a great deal: "One lesson is that to be second is not to be secondary, or inferior; likewise, to be first is not to be originary or authoritative" ( $p$. xv). Applied to translations into Arabic, her view will be instructive, namely the general tendency to "privilege or at least give priority (and therefore, implicitly, value) to what is always called the "source" text or the "original" (p. xx). Traditionally in Arabic studies of translation, a scholar is driven to look for the source text, intent on a comparison that should reveal the degree of faithfulness, or accuracy in transmission. Ibrahim Abdul-Qadir al-Mazini is notorious for departing too drastically from his "sources" so as to produce fine Arabic poems. Abbas Mahmoud al-Aqqad swam against the current of the general disparaging opinion by calling al-Mazini's method the "genius of translation." In the poetical works of Ahmad Shawqi, one finds poems called "from the French", and in the Apollo magazine (1932-4) one encounters many translations, sometimes of the same poem, but which are in fact adaptations. 
In application of Hutcheon's view about the affinity of translation and adaptation, it may be better to see how the two songs sung by the Fool (البهلول) in King Lear are rendered by the same translator (Enani), and occurring in two separate scenes. The first is an 8-line brevity in which the Fool (clown) vows loyalty to his master the king, but the song is addressed to Kent. It obviously contributes to the action, or the plot, as the earlier view of the function of songs claims:

That, sir, that serves and seeks for gain

And follows best for form,

Will pack when it begins to rain,

And leave thee in the storm.

But I will tarry; the fool will stay,

And let the wise man fly;

The knave turns fool that runs away,

The fool no knave, perdy.

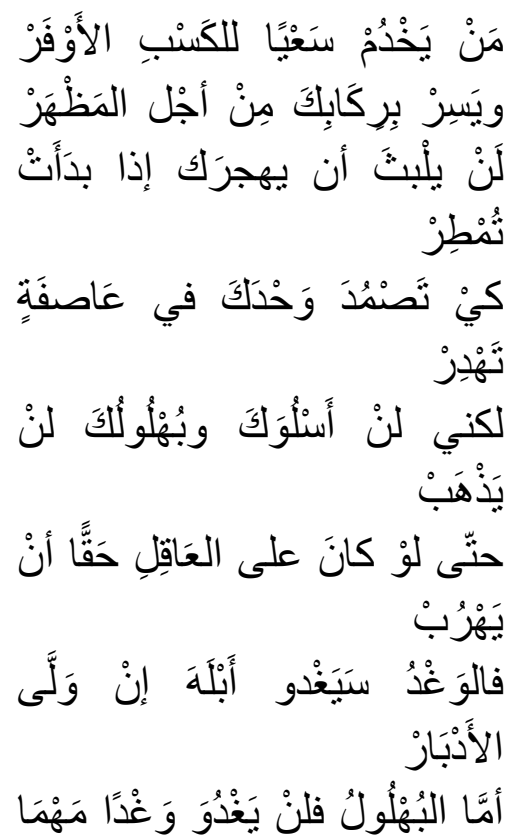




\section{صَاز}

As this is followed by the trials and tribulations of the king, having been betrayed by his two daughters and left alone in the wilderness (on the heath) amidst a raging storm, Kent advises him to seek shelter in a lowly hut, and the Fool now upbraids the King, insisting that he is harebrained. He now sings to King Lear, another functional song (dramatically) before concluding the scene with a 14line comment on the expected deterioration of life.

Fool: (singing)

He that has and a little tiny wit,--

With a heigh, ho, the wind and the rain,--

Must make content with his fortunes fit

For the rain it raineth every day.

(III.ii. 69-72)

With alternating lines of five and four feet, and a single rhyme in lines 69 and 71, the song is sarcastic and has an apothegmatic quality, both reflected in Enani's version:

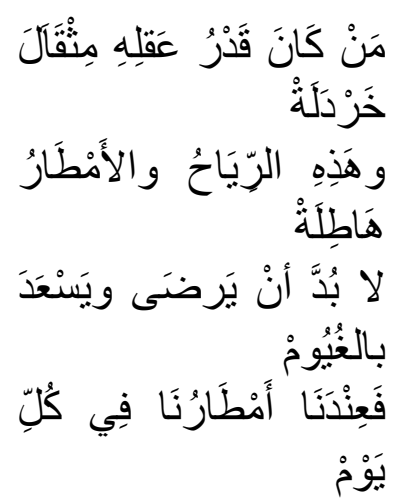

The reference is of course to the character of King Lear, ironically inviting him to be gratified with the storm. When Lear asks Kent to 
take him to the hovel, and both leave the stage, the Fool addresses the audience, delivering what he describes as a prophecy: it is a contemplation of a world deteriorating into an unnatural state of affairs. The "world" he now considers is Albion, that is, England, or "this country". The lines are:

When priests are more in word than matter,

When brewers mar their malt with water,

When nobles are their tailors' tutors,

No heretics burned but wenches' suitors,

When every case in law is right,

No squire in debt nor no poor knight,

When slanders do not live in tongues,

Nor cutpurses come not to throngs,

When usurers tell their gold i' th' field,

And bawds and whores do churches build-

Then shall the realm of Albion

Come to great confusion.

Then comes the time, who lives to see 't,

That going shall be used with feet.

(III.ii.81-94)

Unable to relate the 14-line prophecy to any part of the action in King Lear, some scholars and critics have suspected that its writer may not be Shakespeare, or that the actor playing the part of the Fool may have been the author. Recent research shows it is more likely that Shakespeare himself may have added the lines, either at the request of the 'Player' or as a relief from the tension now building up to a climax, as the next scene sees Edmund's plotting against his father, the King, followed by the King himself battling the elements. The 14-line 'piece' has rhyming couplets, in tetrameter, and offers a bleak picture of the 
future, thematically but not dramatically connected with the action. This is how Enani renders it:

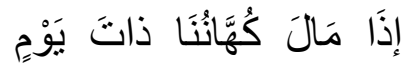

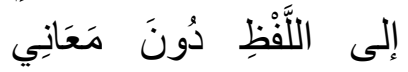
الكَلَّم

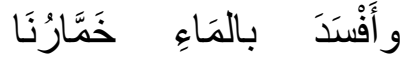

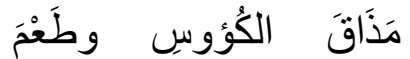

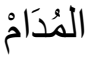

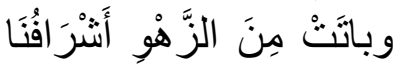

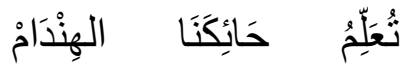

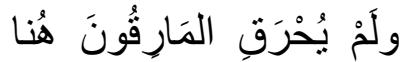

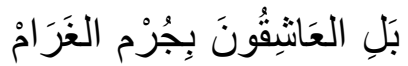

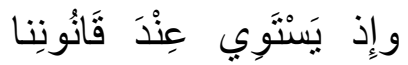

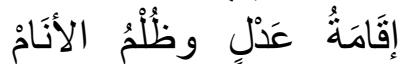

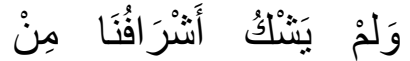
دَيُونِ

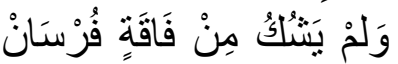

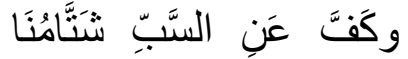

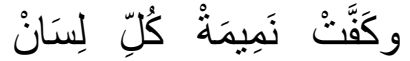

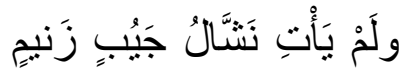

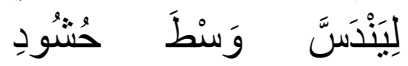
الزََّحَاْ

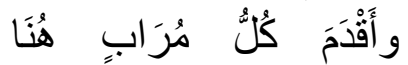

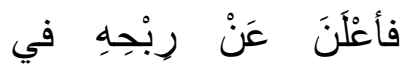
الحَرَاُْ

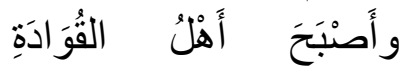
و المُوِوِسَّاتُ

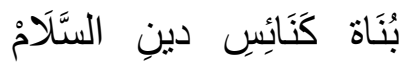

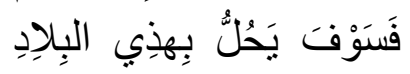

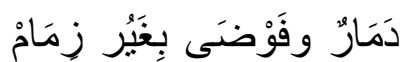

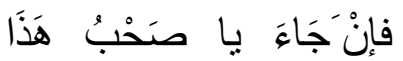




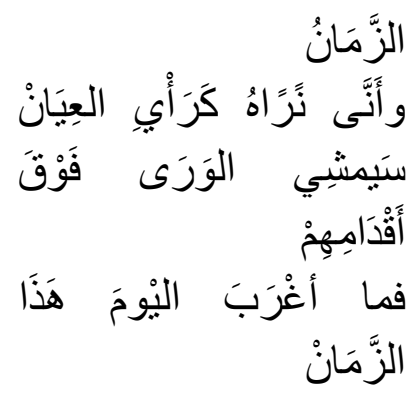

As all passages cited are translated by the same person, namely M. Enani, differences in style must be attributed to his conception of the function of each in the play. The first two are close enough to the source text. Their reference is to anyone: "He who is", or "he who seeks", but obviously their deixis is to the King himself and his Fool. The possessive (K) (ك) in Arabic (بركابك), (وحدرك)) precedes the deictic shift to the first person pronoun, "But I" (لكني), again before the final mixing of the first, second and third person pronouns in the last three lines in the first cited passage (II.iii.72-9).

The same may be said of the song secondly cited (III.ii.69-72). "He that has and a little tiny wit" obviously references the King himself, and that it is 'he' (Shakespeare's 'that') that should be "content" with his "fit fortune" in being drenched by the rain; only the conclusion suggests that the fool is referring to the present situation with a place and personal deixis, namely (عندنا) and (أمطارنا) with the possessive plural pronoun added by the translator as though by way of explicitation. It is the use of this pronoun in the third song that in Arabic establishes the reference to all people. A sentence like "It is not 
considered in good taste to look a gift horse in the mouth" may be translated as:

$$
\text { [نرى أن] الذوق السليم يقتضي ألا ننظر بارنياب في هدية تهدى لنا }
$$

In technical terms, this personal pronoun is generic, i.e. "our" means "anyone's"; in other words, it is not referential, i.e. referring not to the speaker (with the royal plural) or to their specific people. Being generic, the pronoun may refer to all humankind. However, the referential function may not be excluded. By establishing the referential function in the opening line, the Fool is talking about a specific country (Albion=هذي البلاد) and its people. This is consistently confirmed by several similar pronouns as well as place deictics, namely 'here' هنا(ه). These specific deictics are not given explicitly in the source text, but supplied by the reference to Albion in line 91. Accepted as interpretation, it also allows the lines to refer generically to any country, and to any people, and to give a connotative independence lacking in the earlier passage. This is made possible by the fact that the features and agents of future "great confusion" do not appear in the play's action explicitly at this point. That these signs may or will appear in the future allows the reader to get both generic and referential signification at the same time. It is an interpretation which suggests adaptation.

The verse form adopted in the translation may also be regarded as an attempt by the translator to appropriate the lines. The regular meter (different from those of the previous passages) and the 
alternation of the close rhyme words ending in M (نون) (نيم) and N) combine to present a unified vision not meticulously corresponding to that in the source text. In other words, you can read the fourteen-line prophecy as complete in itself and perhaps applicable to any other situation, in any given country. This is not what one finds in the earlier excerpts. It is an instance of how translation can be an adaptation and, up to a point, an appropriation.

\section{Limits of Adaptation and Appropriation}

If we accept the view that every literary translation is a form of adaptation in the sense of fitting one cultural verbal medium into another, it will be easier to accept and account for the many translations which read differently of a given text across many languages or into the same language across different eras with different cultures. However hard a translator works to adhere to the language molds of the source text, the way they reproduce these putatively specific molds into the target text, he or she will, almost unwittingly, use their own 'natural', acquired or favored verbal mode. As the latter decisively pertain to the translator's culture, the process of translation may be thought of as "transcoding." However, if a poet-translator adapts a source text in the way they handle their verse, their muse may interfere and make the target text half-belonging to them. If the muse's interference exceeds a certain limit, it will turn the translator into a co-author, claiming part of the adaptation process as the translator's own-hence a degree of appropriation. 
If the adaptation is limited to minor additions and/or omissions it is normally passable and acceptable as more or less inevitable. However, if the muse's work introduces changes which transform the character of the source text, then the adaptation will bespeak appropriation. An example of the translation of Shakespeare lyric "Take, O take those lips away" (Measure for Measure, IV.i. 1-8) by alMazini and Enani (cf. The Art of Translation in Arabic) will show the former adding a whole hemistich in the first line, a conditional uncalled-for in the third line, and an adjectival phrase in the same third line in the Arabic translation (where a line is a distich, consisting of two hemistichs). The addition of the last phrase may be required culturally, as a kiss in Arabic is thought, without undue prudishness, to be on the cheek. The omission of the key word "forsworn", given an end focus in the English, mars the meaning by not showing the reason why the poet wants to get away from both (lying) lips and beguiling eyes. This translation turns the adaptation into an appropriation.

The question of translation being adaptation is handled by Linda Hutcheon in her A Theory of Adaptation, 2013 ( $1^{\text {st }}$ edn. 2006). She says:

As openly acknowledged and extended re-workings of particular other texts, adaptations are often compared to translations. Just as there is no such thing as a literal translation, there can be no literal adaptation. Nevertheless, the study of both has suffered from domination by "normative and source-oriented approaches" (Hermans, 
1985:9)...[I]t is important to remember that, in most concepts of translation, the source text is granted an axiomatic primacy and authority, and that most rhetoric of comparison has most often been that of faithfulness and equivalence. Walter Benjamin did alter this frame of reference when he argued, in "Task of the Translator" [in Schultz and Biguenet, eds., Theories of Translation, 1992] that translation is not a rendering of some fixed non-contextual meaning to be copied or paraphrased or reproduced; rather it is an engagement with the original text that makes us see that text in different ways (p. 77). Recent translation theories argue that translation involves a transaction between texts and between languages and is thus "an act of both intercultural and intertemporal communication" (Bassnett, 2002, 9) [Translation Studies, 3rd edn.] (Hutcheon, p. 16)

Examined in the light of this newer sense of translation, Enani's rendering may be seen as a "transcoding" of the source text: his additions are part of his cultural adaptation. To "wine" he adds "alcoholic drinks" (المُدام); to "nobles" he adds "out of vainglory" ( (الز هو); he interprets “wenches' suitors" as (العاشقون بجرم الغرام); he adds to "cutpurse" a qualification of "wickedness" (زني); to the "usurer's gold" is added "unlawful profit" (ربح حرام); Christianity is rendered as the "religion of peace" (دين السلام); and finally, "great confusion" is given as (دمار وفوضى بغير زمام), that is, unbridled destruction and chaos. In the language of the new media, Hutcheon explains, this is "reformatting" (p. 16). She cites Robert Stam's conclusion that every 
adaptation involves "gain and loss" (Stam, "The Dialogics of Adaptation", 2000). In terms of building up an autonomous Arabic poem in a regular meter, bolstered with rhyme, Enani's adaptation may involve more gain than loss: the change of deictics agrees with normative Arabic idiom, but hardly anything significant is added.

Another important contribution by Hutcheon to the theory of adaptation is her recognition of paraphrase as a means of adaptation, common and acceptable. If Enani's version can be shown to be appropriation, all prose renderings of the above-quoted lines can be considered a species of paraphrase without any claim to appropriation. Such paraphrases do not always prove faithful to the source text: some may try to improve the phraseology of the original, as Mutran does, rendering Shakespearean verse: he uses pompous Arabic idiom, sometimes obsolete, to raise the 'quality' of his prose; others cannot always get the meaning right, ignoring what Shakespeare's editors and commentators say. One such case is Badawi's rendering of the abovecited prophecy of the Fool in King Lear. A comparison with Enani's version shows that the prose unnecessarily changes the sense and in trying to cut corners, condenses sentences or collapses two into one, with unfortunate results from the hand of an Oxford don. Here is his version:

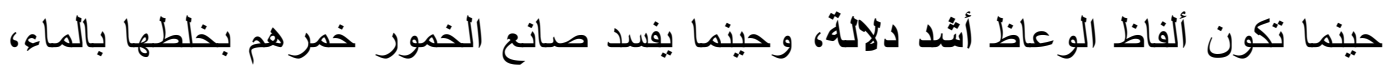

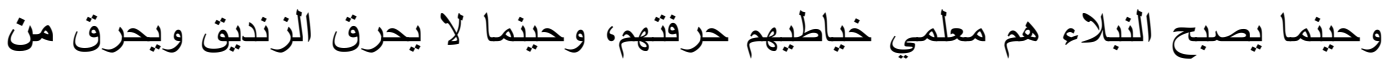

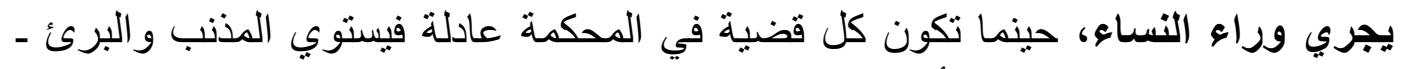

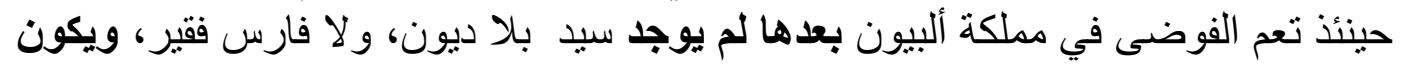




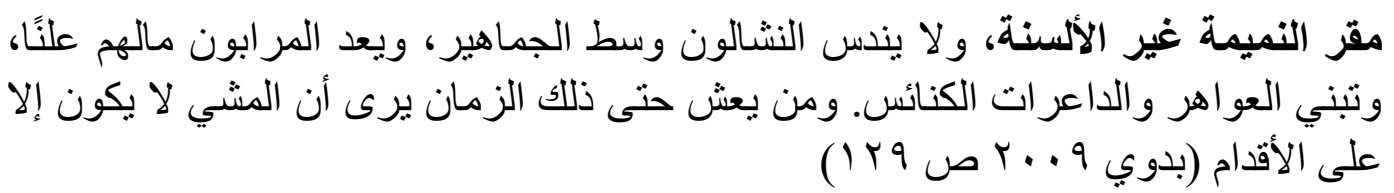

Although notorious for its ambiguities, as thus befitting the Fool's own wry logic, the drift of the prophecy is that a "great confusion" (glossed as chaos and ruin) will occur to England if certain conditions appear. These are mostly cases of the reversal of the natural order of things. Priests sacrifice sense for sonorous verbiage; wine makers "mar" wine; nobles teach their tailors their trade; lovers (suitors of maids in marriage) are burned instead of heretics; law courts cannot distinguish the guilty from the innocent. Up until Line 5, the reversal is maintained but is interrupted by the liberation of members of the aristocracy from debts which by our standards is a positive development, soon to be followed by equally good signs, namely: the slanderers refraining from using their tongues; cutpurses refraining from practicing their trade; usurers being explicit about their unlawfully acquired wealth; and finally the anomaly of pimps and harlots building churches.

So far, the first five lines establish an image, basically negative, of the future, while the next five lines are ambiguous and can be differently interpreted. One or two critics have called this a contradiction; others argue that no consistent point of view should be reached from the Fool's words as, after all, he is building up a case of "great confusion.” By definition, 'confusion' can include positive and 
negative elements. This is beautifully exhibited in the last paradoxical couplet: in line 93 the Fool wonders if he will survive to watch the "great confusion" and in line 94 he says that people will then walk on their feet! The sense of confusion is explicitated by the hemistich added to the Arabic verse rendering, namely "how strange that time will be!"

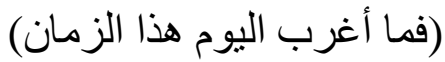

In both verse and prose renderings, an adaptation is made, but the earlier adaptation in verse (1996) gives the adaptation an air of appropriation, while in the second, in prose (2009) the adaptation is

closer to a paraphrase trying to produce a consistent argument by merging the unmerged two sides of the Fool's prophecy, still apparently deferring to the source text.

\section{Arabic Songs in The Merchant of Venice}

Written as a romantic comedy, with two intertwined plots, one of which is based on the meaning of love, friendship and fortitude, the other on the value of mercy, The Merchant of Venice is full of songs capable of belonging to both views offered in the opening of this essay of the function of a Shakespearean song. Marked in the text as 'songs', occurring in the casket scene, they are rendered in verse by two major translators (Mutran and Enani) and as prose by another eminent writer, al-Wakeel. Besides the 'formal' songs, some passages are written in 
kinds of verse which brings them closer to the lilt of songs, tempting the translator to render them either into verse or in rhythmical prose. The first casket scene contains the introduction of the three caskets by the Prince of Morocco:

Morocco: The first is of gold, who this inscription bears:

"Who chooses me shall gain what many men desire."

The second, silver, which this promise carries:

"Who chooses me shall get as much as he deserves."

The third, dull lead, with warning all as blunt:

"Who chooses me must give and hazard all he hath."

(II.vii. 4-9)

The first version by al-Wakeel, in prose, may be regarded as a paraphrase, clear and close enough to the source verse:

الأولى من ذهب وهي تحمل هذه العبارة "سينال من يختارني ما ير غب فيه الكثير من

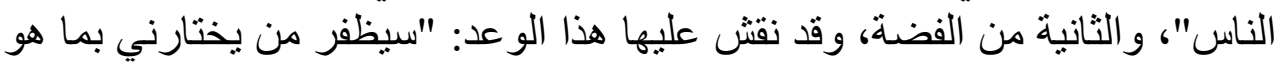

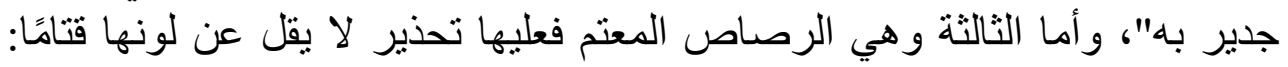
"يجب على من يختارني أن يعطي وأن يقامر بكل ما يملك."

(ص9)

A recognized poet, Mutran realizes that the inscriptions should be distinguished by being in verse, and possibly in rhyme, which he actually does in his rendering of the six lines:

$($ (

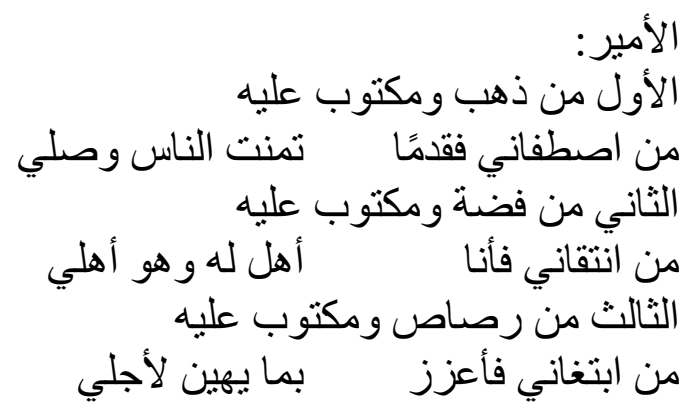




\section{Dr_Shaymaa Adham Basheer (BIJHS) Vol.3 Issue 1 (2021)}

The three distichs are written in the same meter, viz. Al-Mugtath, and share a single rhyme scheme. The language is deliberately, like the translator's own rhetoric, slightly antiquated. It is here that we begin to hear Mutran's own voice, one that adds a certain tone to the passage, enabling the listener or the reader to feel the difference between prose and poetry. In the adaptation, a touch of appropriation is discerned.

In contrast, Enani's version is all in verse, and the lines on the caskets are unrhymed. The meter is the modern Khabab, which is close enough to both the iambic and trochaic beats. It is also close to the source divisions, like Mutran's, reflecting the structure of the six lines. Here it is:

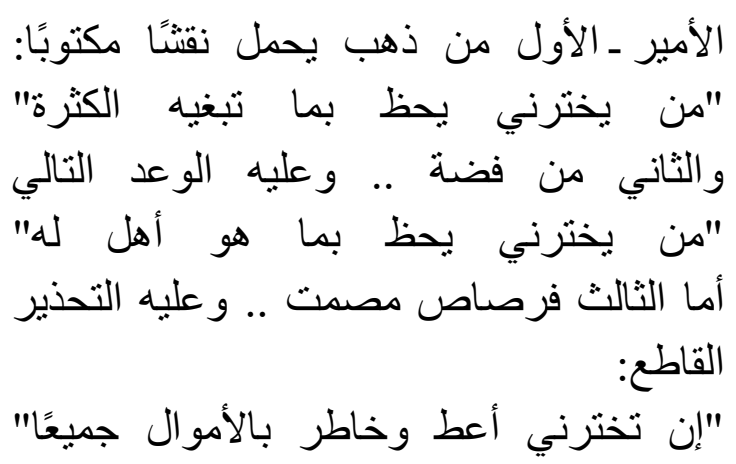

- irr ص)

$(1+9$

The adaptation to Arabic verse uses Modern Standard Arabic, which is the common language of writing and the 'respectable' media and is therefore shared by the translation and its contemporary audience. No attempt at appropriation is felt in the Arabic lines: nothing significant is added, even the qualification of lead as 'solid' 
(مصدت) instead of 'dull' (بليد) - an adjective omitted by Mutran changes little in the source text. While Mutran omits the adjective 'blunt' and al-Wakeel translates the adjective as (قاتم), Enani gives the apparently intended meaning which is (قاطع) (straightforward or categorical).

The next song, or lyric, found in the casket by the Prince of Morocco, is deliberately well-wrought. It is written in tetrameters, with the occasional modulations (الزحافات و العلل) such as the omission of a final or penultimate unaccented syllable. Rarely in Shakespeare do we have a single rhyme for 9 consecutive lines. Mutran's solution to the rhyme problem is to build his Arabic song into four distichs having a common rhyme, which is the rule in classical poetry; Enani's solution is to have a single rhyme for the first five lines, then four monostichs with alternating rhyme words. But first let us have the English song:

Morocco: (Reads)

All that glisters is not gold, Often have you heard that told.

Many a man his life hath sold

But my outside to behold.

Gilded tombs do worms enfold.

Had you been as wise as bold,

Young in limbs, in judgment old,

Your answer had not been inscrolled.

Fare you well. Your suit is cold.

(The Merchant of Venice, II.vii. 56-73)

The apothegmatic quality of the opening line suggests that the intended audience is every reader or member of the audience as well as the Prince of Morocco. This is a device common in Arabic as it is in 
English. Sometimes it occurs in a soliloquy, but more often in separate lines meant to be proverbial. In Ahmad Shawqi's The Death of Cleopatra (مصرع كليوباتر), the heroine says in her valedictory speech:

$$
\text { وبعض السم ترياق لبعض وقد يشفي العضال من العضال }
$$

One poison's antidote may be another poison;

The cure of a terminal condition

May be a fatal infection.

The same device may be used as impressive opening lines, regarded as a clever opening: an example of such a clever opening (براعة (الاستهلال is Abou Tammam's

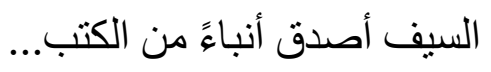

The sword carries more truthful tidings

Than any letters arriving...

A clever opening of an elegy lamenting the death of a crucified potentate says:

$$
\text { علوّر في الحباة وفي الممات لحق أنت إحدى المعجزات }
$$

So high in life, in death so high,

A miracle you exemplify.

A wise saying, or a saw, is characterized by brevity, the memorable nature of verse, the simple diction, and the possibility of various interpretations. So Abou Tammam's hemistich, quoted above, is not only pithy but allows the rhyme word to mean more than 'letters'; it may, and indeed does, refer to books in its usual sense. The second hemistich of the Arabic line confirms both senses, (في حده الحد بين الجد 
(و اللعب Apart from the word play and antithesis, it can refer to books as containing information which is unconfirmable. In English one might say:

Decisively the sword's edge makes the way

Serious work is separated from play.

In each case, an apothegm is characterized by a strong rhythm, often metrical, and can stand by itself or link with an adjacent line. In other words, the proverbial structure tends to be more paratactic than hypotactic. When the Prince of Morocco reads these lines, he gives us a line worthy to stand out as a response to his failure: he bids Portia farewell, realizing that he is now condemned to celibacy, but in words that may apply to other, similar situations:

Then farewell heat, and welcome frost. (75)

The prose rendering does not do this justice. Mutran renders it as:

$$
\text { وداعًا أيها الغر ام المحرق! سلام عليك أيها القلب الذي لا يكترث! (ص7؟7) }
$$

Al-Wakeel gives:

$$
\text { إذن فوداعًا يا آمال الحب الحارة، ومرحبًا بحياة البرودة والحرمان! }
$$

The latter is satisfactory as a paraphrase, but the apothegmatic quality is to be found in Enani's

$$
\text { فوداعًا يا ربيع ومرحبًا بك يا صقيع! }
$$

Let us focus therefore on the poetic quality of the lines as translated in the two verse versions. Here is first Mutran's: 


$$
\begin{aligned}
& \text { قل كائنًا من كنتَّ عن ثقـة ما كل براق من الذهب } \\
& \text { عظة هي الكنز النفيس فلا } \\
& \text { الحقب } \\
& \text { لو كان رأيك غير مختلط في حين شعرك غير } \\
& \text { ما عدت هذا العود في ندم وبمثل هذا الرد لم تجب }
\end{aligned}
$$

$(77-70)$

Enani:

$$
\begin{aligned}
& \text { ما كل براق ذهب مثنلٌ يدور على الحقب } \\
& \text { كم باع شخص روحله كيما يشـاهدني وحسب لئب }
\end{aligned}
$$

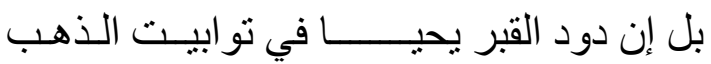

$$
\begin{aligned}
& \text { لو كان ذهنك ثاقبًا كثجاعتلك } \\
& \text { وحويت في جسم الثباب حصافة دهاعة } \\
& \text { الثيخ الهرم في جام } \\
& \text { ما جاء هذا الرد على رسالتكا } \\
& \text { اذهب وداعًا قد خسرت بخطبنكاء }
\end{aligned}
$$

$$
\text { ( } 1 \leq \cdot-1 \% q u)
$$

The single pithy line is turned into two distichs by Mutran (4 hemistichs, two of which are unnecessarily added). There is no dramatic or other need to omit the reference to people sacrificing themselves so as to "behold" gold, or the fact that gilded coffins contain maggots. The idea of sacrificing life for gold only to have it in death, a typical Shakespearean antithesis, is also lost. Mutran's metonymies - "if your mind is not confused" (رأيك غير مختلط) for "wise" and "while your hair is not henna-dyed" (في حين شعرك غير مختضب) for "young" are all the translator's. They testify to the tendency to appropriate the lines, especially as Mutran in the adaptation process 
allows himself to suppose that the anonymous lines can express the Prince's regret (ندم).

The initial rhyme words in Enani, (ذبب) and (حقب) may reveal an unconscious memory of Mutran's lines, or a conscious one; it is unlikely that two translators should have hit upon the same rhyme words by chance. The former may be naturally used by all translators, as gold is the theme of the song, but al-hiqab suggests Mutran's influence. However, while both translators share the same metre in Arabic, the shorter variety of this meter, as used by Enani, does indicate that his version, or part of it, would be proverbial. The first five lines in the English song are rendered into three distichs containing 6 hemistichs. The last four lines in the source text consist of a single 3line hypotactic sentence, plus a single-line conclusion. Enani reflects this structure by using short paratactic sentences in the first part, then creates a kind of barrier marking the deictic shift: now the poem will be addressing the Prince of Morocco. However, while all the feet (تفعيلات) belong to the same meter, with each hemistich in the first part of the song consisting of two feet, the monostich barrier consists of three feet, clearing the ground for the regular 3-foot-hemistich norm. The new

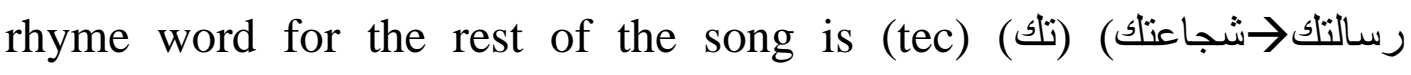
$\rightarrow$ (بخطبنا) which ensures that the poem now is addressed to the Prince. So while - like Mutran - Enani aspires to produce apothegmatic sayings, as he does in the first three distichs of his Arabic text, he goes back to the dramatic situation by addressing the prince. 
Can it be said that these two translators shared the impulse of rewriting the song, with one of them more thoroughly changing it so that it now looks more appropriative? If considered independent poems based on a Shakespearean song, can they be regarded as attempts to interpret a source text in ways that make the source less of an authoritative text, and more of an inspiration of each - in different ways? In other words, where does one draw the line between objective and subjective adaptation? However, if a line has to be drawn at all, it should be between an adaptation and what is thought of (or was once thought of) as an 'original'. The late $20^{\text {th }}$ century literary theory has claimed, in structuralist and post-structuralist studies, that the concept of originality in writing should be reconsidered, if not denied. This claim may have had its origins in Claude Levi-Strauss' thesis, emerging from his studies in anthropology, which claims that the structures of thought, in whatever form, are repeated across cultures (Myth and Meaning, 1978 [2001]). In his "On Originality", Edward Said says that "the writer thinks less of writing originally and more of re-writing" (The World, The Text and the Critic, 1983, p. 185). More relevant is Jacques Derrida's idea that in writing, as in translation, the desire for expression is "the desire to launch things that come back to you as much as possible" (The Ear of the Other: Otobiography, Transference, Translation, 1985, p. 157). Derrida's odd spelling of 'autobiography' is meant to merge 'other' with 'auto', so that when one 
thinks that one is writing about others, one is actually writing about oneself, and vice versa.

This idea is made more explicit in Roland Barthes' contention that in literature "any text is an intertext" ("Theory of the Text" in Untying the Text: A Post-Structuralist Reader, ed. R. Young, 1981, p. 39). Barthes means that the works of previous and surrounding cultures are always present in literature, so that works are not solely dependent on their authors for the production of meaning: they may have benefited from their readers who create their own intertextual networks. Readers with a knowledge of heritage Arabic will find in Mutran's Shakespearean translations different meanings from those found by readers brought up on Modern Standard Arabic. Mutran's text will be part of an intertextual network, extending as far back as the Arabic of pre-Islamic Arabia. So, according to Barthes, readers of Mutran in the 1920s contributed to his style both in writing and translating poetry, as much as readers of Enani, brought up on MSA, have contributed to his writing and translation of poetry in the 1980s. The literary environment, including living traditions, interferes in the building of an individual poet or translator, so that the result is produced by more than the talent of the individual: it is here that we see Arnold's power of the man and power of the moment coinciding.

If the line separating an 'original' work from the various factors influencing or contributing to it is at best fuzzy, so should the line separating a translated literary text from such factors. Therefore, if the 
'original' and translated literary texts are produced within the same culture, and about the same time, such factors (as defined by the socalled French Theory) may be identical, and the old question of 'accuracy' or 'equivalence' will rear its head. It is when the source and target texts are produced within different cultures and at different periods that the consideration of these factors will be of paramount importance. Insofar as these factors are decidedly different, any assessment of the translation will have to take them into account: if too powerful, and thus irresistible, they may influence a translator's style more than the source text. One of these factors, of course, is the need to shape the reader's response, and, in this case, the translator will give priority to the text's perlocutionary force over both "locution" and “illocution" as defined by Austin (Things To Do With Words, 1962).

This may be the case with Mutran's rendering of the song sung by silver, in The Merchant of Venice:

The fire seven times tried this,

Seven times tried that judgment is,

That did never choose amiss.

Some there be that shadows kiss.

Such have but a shadow's bliss.

There be fools alive, iwis, Silvered o'er-and so was this.

Take what wife you will to bed,

I will ever be your head.

So be gone. You are sped.

(II. ix. 62-71) 
Insofar as any paraphrase is acceptable in translating poetry, alWakeel's Arabic version is passable. It gives the 'skeletal' idea which personified silver presents, namely that because silver is refined by seven processes of melting in fire, it has no impurities, and its judgment is always right. Certainly (iwis) some people are deceived by things 'silvered over' and so 'kiss' the appearance and not the substance, such as you, Prince of Aragon. They are fools, as much as you are: so put the dunce's cap on your head and go. Shakespeare makes the mistake of letting silver ask the Prince to marry whomever he wants, because this breaks the oath (or the vow) to be condemned to celibacy by the loser. Here is the prose rendering by al-Wakeel:

$$
\begin{aligned}
& \text { أمير أرغونة: (يقر أ) لقد تطهر هذا في النار سبع مرات، ولقد محص هذا سبع مرات، } \\
& \text { ولم يحدث من قبل أن طاش سهم اختياري. بيد أن من الناس نفرًا يقبلون الأشباح، } \\
& \text { و أولئك لا يظفرون من السعادة إلا بخيالها العابر، و لا مراء أن بين الأحياء بلهاء، } \\
& \text { يبدون في مظهر أسمى من حقيقهم، وتللك حال تللك العلبة، فلتنزوج ممن شئت، } \\
& \text { فسأظل أنا على المدى رأسك! إذن فانصرف فلقد أنجزت مهمتك. (ص997) }
\end{aligned}
$$

However, as paraphrase, it cannot be aesthetically equal, or merely comparable to the verse and its techniques. The translator tries to 'elevate' the prose style by using a common idiom in Arabic about an arrow shot but gone astray, but changes the significance of "silvered o'er" as the condition of the casket: Shakespeare repeats 'this' of the first line to make it refer to the speaker, silver, not as in the paraphrase, the 'condition of the casket'. The first person pronoun in the penultimate line refers to the dunce's cap or the fool's head, but the 
prose rendering repeats 'this', which throughout refers to silver. In attempting to adhere too closely to the words of the song, the translator misses one or two meanings.

Even as an adaptation, every paraphrase is inevitably checked for accuracy against the source text it tries to replicate. "This" appears as

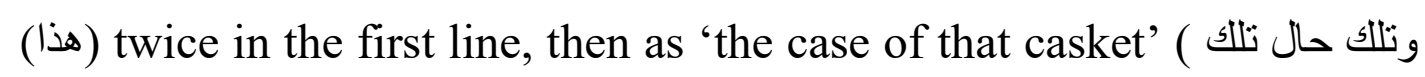
(العلبة) and finally as 'I' (أنا). Instead of explicating, the paraphrase confuses the sense by not linking the words to the dramatic situation, the paraphrase may be an adaptation, but, lacking in accuracy and aesthetic quality, makes an inept representative of the source text.

On the other hand, Mutran's five distichs declare from the beginning that it is an Arabic poem in imitation of Shakespeare's lines. He uses his own language, immersed in heritage Arabic, which does not invite the reader to go back to the source text. His opening formula is the spurious conditional, previously mentioned. His man (من) is technically a substitute for 'if', meaning 'while' or 'whereas'. One is reminded of Shawqi's

$$
\text { ومن يغتر بالدنيا فإني لبست بها فأبليت الثيابا }
$$

If there are men who wrongly trust this world,

I am not one of them,

For I tried on all her garbs and wore them out.

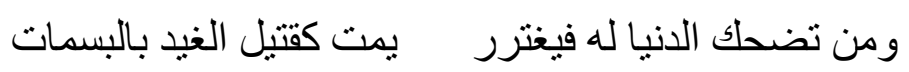

If a man is deceived by a smiling world,

He'll end up dead

Like the victims of maidens' smiles. 
Mutran establishes his appropriation primarily by adopting a classical module: his idea may be the opposite of what Shakespeare says, but then he shows less interest in the idea than in producing an Arabic poem worthy to be enjoyed. Let us see how he translates the lines:

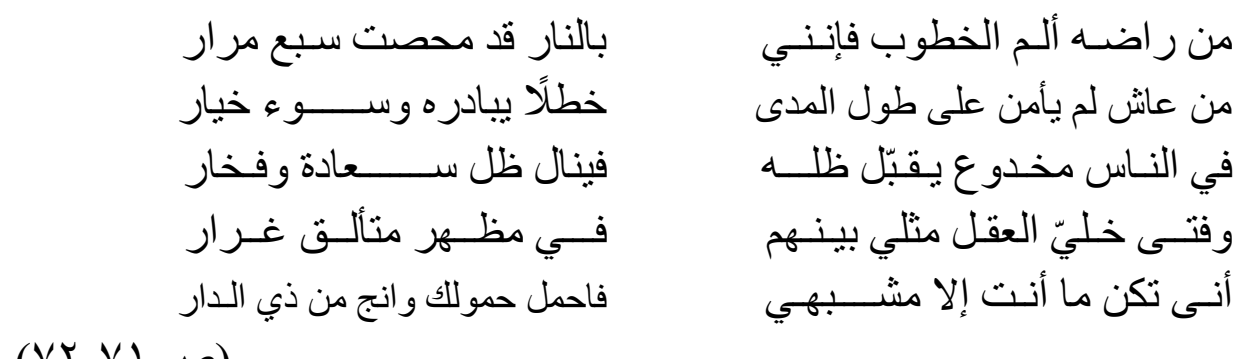

$\left(V Y_{-} Y\right)$

Paraphrased, the lines say that while some people are broken by the pain of disasters, I have been seven times purified by fire. All living men are not safe from error and bad choice. Someone may be deluded and so kisses his shadow, gaining a shadow of happiness and pride. You'll meet an empty-headed man somewhere, with a glittering, tempting appearance. Whatever you are, you're just like me; so pack up and save yourself from this house.

If the difference between adaptation and appropriation can lie in the degree of explicitness of expressing their purpose, as Julie Sanders argues (2006, p.8) then Mutran most explicitly shows his appropriation intention. To begin with, he adapts the idea of being tried by fire as 'trials and tribulations' - the 'pain of disasters'. The second distich accepts 'bad choice' as a possibility to which everybody is prone, including silver and the Prince. The opening (מن) is inclusive. The third 


\section{Dr_Shaymaa Adham Basheer (BIJHS) Vol.3 Issue 1 (2021)}

distich is close enough to the Shakespearean image, with the doubling (سعادة وفخار) having an end focus. Omitting the reference to a wife, Mutran uses one of his common formulas (كائنا ما كنت) $\rightarrow$ (أنى تكن) etc. to indicate the Prince's similarity to silver! Finally we have the uncalledfor advice to the Prince to "save himself from this house!" The addition and omission will therefore be acceptable as part of the appropriation process but will hardly establish the Shakespearean text to the Arabic reader. Now let us examine how this is translated. To begin with, the translator, as dramatist, establishes the situation on the stage, adding or expanding the stage directions already in the text. All editions give the following stage direction:

([The Prince] unlocks the silver casket.) Arragon then says:

What's here? The portrait of a blinking idiot

Presenting me a schedule! I will read it. (53-4)

$$
\text { ماذا أجد هنا؟ صورة معتوه غماز في يده ورقة! فلاققر أها! }
$$

At Line 61, he repeats "What is here", and Enani adds his own stage directions as part of the adaptation process; these say,

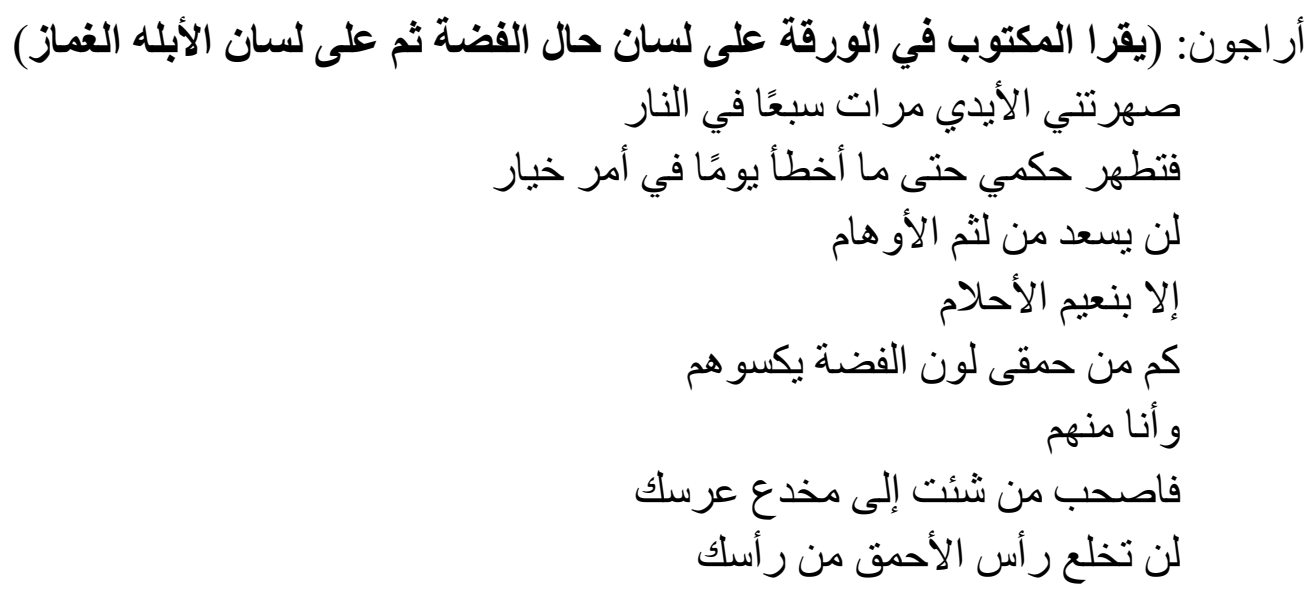




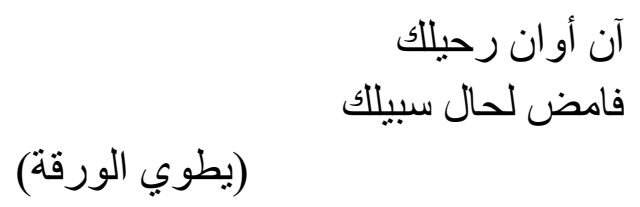

The adaptation is limited to the addition of stage directions which link the song closely to its context. After all, we are watching a scene, which means we have immediacy of action (حضورية الحدث): we hear the words as we watch the action. The change from the silver speaking to the speech of the "blinking idiot" at the $6^{\text {th }}$ line is marked by the short monostich requiring a pause in the delivery. The "I" in the penultimate line Enani changes to (رأس الأحمق). This seems logical as that which will be "ever your head" refers not to silver but to the head of the "blinking idiot". Adhering to the dramatic situation categorically tips the translation into dramatic adaptation.

Mutran's tendency to appropriation reaches a climax when a professional singer, complete with a chorus repeating the refrain after him, is presented in III.ii. 63-72. Let us first have the song:

Singer: $\quad$ Tell me where is fancy bred,

Or in the heart, or in the head?

How begot, how nourished?

All: $\quad$ Reply, reply.

Singer: It is engender'd in the eyes,

With gazing fed; and fancy dies

In the cradle where it lies.

Let us all ring fancy's knell

I'll begin it. Ding, dong, bell.

All: $\quad$ Ding, dong, bell.

(III.ii. 63-72)

The key to Mutran's appropriation intention is his choice of Arabic metre for the song. The point of the song is simple, common 


\section{Dr_Shaymaa Adham Basheer (BIJHS) Vol.3 Issue 1 (2021)}

and easy to grasp: attraction to a lady's beauty gives the viewer an illusion that he is in love. However, this is only "a fancy", an imagined love, and the proof is given in the second stanza, namely that it dies in its cradle. The singer then marks the death of an illusion, implicitly calling for real love, heartfelt emotion, in its place. Here is Enani's version:

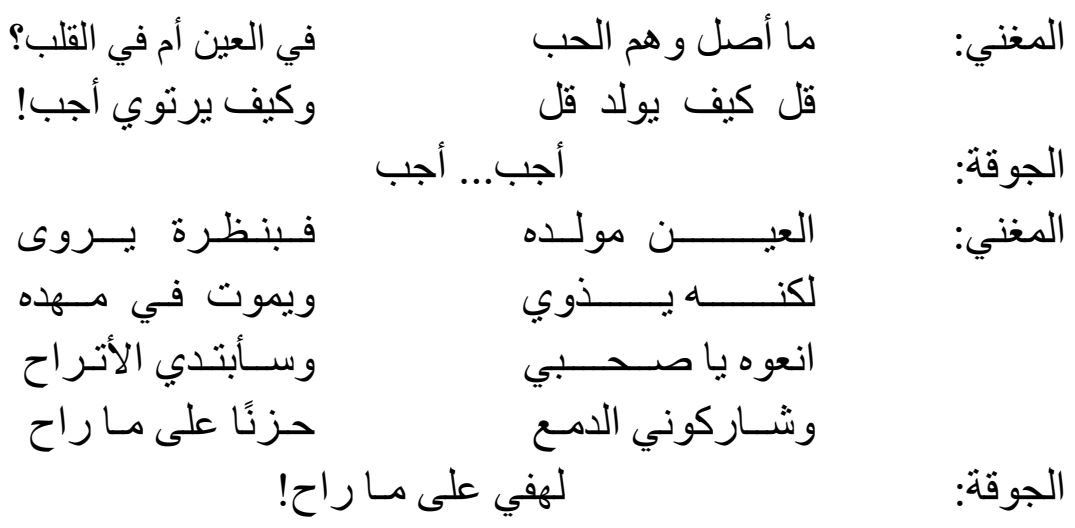

Al-Wakeel's prose rendering (p. 81) need not bother us, for it remains a paraphrase echoing the source text so closely that it can hardly be described as adaptation. Mutran's version is, however, an adaptation suggesting appropriation. A predominant factor determines this, namely an Arabic metre called Al-Monsarih, (المنسرح) a rare metre used by the great poets, old and new, and showing true competence at versifying. Modern poets who use it reveal an aspiration to rival the ancients. Among the great poets of the past we have al-Mutanabbi. Take the opening of his elegy on the death of Taghlib Ibn Dawood, thus:

$$
\text { مأنف من ميتـة الفركت علة بــورود }
$$




$$
\text { ومثله أنـكر المـــات على غير سروج السوابح القود }
$$

Never a sickness a sick man gripped

More gracious than Taghlib Ibn Dawood;

Too proud to accept death in bed

Now the truest promise has been fulfilled.

Like him was he whom death disavowed

Not mounted on the saddle of a steed.

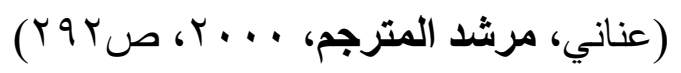

Among contemporary poets who accepted the challenge of this metre was $\mathrm{Abu}$ Hammaam (the pen-name of the late Abdul-Latif Abdul-Haleem), who produced a whole volume of verse entitled "In the Shrine of Al-Monsarih" (في مقام المنسرح). Now Mutran surprises the reader by departing almost totally from the source text, to give us 3 couplets, instead of the original ten lines, with each in a different Arabic metre: al-Monsarih, al-Mugtath, and al-Mutaqarib. ${ }^{1}$ The result is a number of Arabic lines which neither read as a poem nor owe much to the Shakespearean song. 'There is a method' in his imitation: In each couplet, the first line draws on the Shakespearean source, the second is Mutran's own; and has three voices in his song, each using its own metre, the first two are single singers, the third is the chorus. So this is Mutran's song:
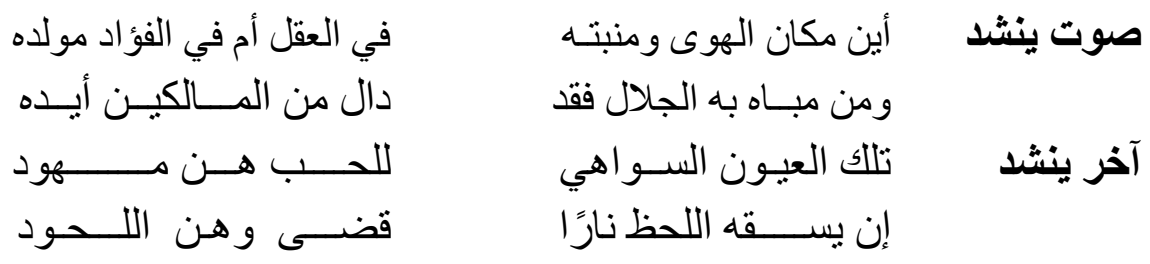

\footnotetext{
${ }^{1}$ I have received help in the analysis of Arabic prosody from Dr. Morsi Awwaad, of Port-Said University (private communication).
} 

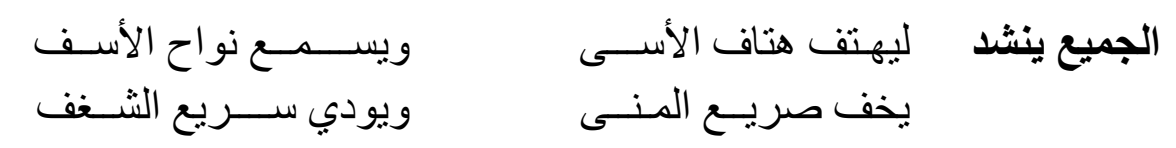

(^) ص)

However, Mutran has another surprise for us: a couplet of $A l$ Monsarih may have indicated his mastery of Arabic prosody, but (he must have wondered) is it enough? He who has the craft of verse at his command must regale the reader with a few more of the same. An opportunity appears in the third and final casket scene, when a scroll inside it addresses the reader in metre and rhyme. There are only eight lines; let us read them in English:

You that choose not by the view,

Chance as fair and choose as true!

Since this fortune falls to you,

Be content and seek no new,

If you be well pleased with this

And hold your fortune for your bliss,

Turn you where your lady is

And claim her with a loving kiss.

(III.ii. 131-8)

Enani gives us a translation that departs but little from the source text, showing that however freely he undertakes linguistic adaptation, his focus is consistently on the source text. Free from ambitions of appropriation, his text is as close as possible to the ideal of faithfulness in translation. Here is what it says:

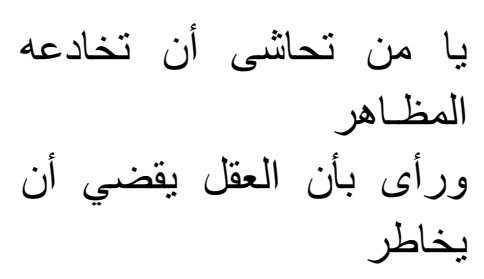




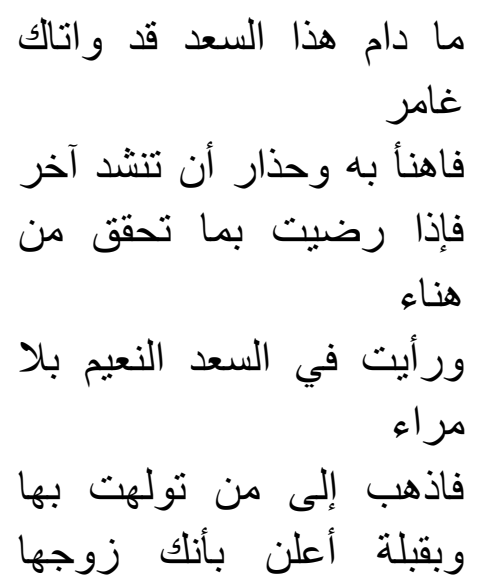

One need hardly emphasize how few Enani's additions are to the Shakespearean song. The opening line contains a word confirming the opposite of the rhyme word in the second line: 'to choose true' (or right) is not to be 'deceived'. The implicit antithesis is thus made explicit. Two words are apparently added to maintain the rhyme scheme, namely (بلا مراءs) and (غامر). Their qualification of the preceding nouns is minimal. In fact, they can be omitted with hardly any change in the sense of the lines. Such verbal adaptation is nearly always acceptable in the translation of poetry.

Now look at the four distichs written by Mutran. They are cited in full, with no comment as the reader can see how the four lines of alMonsarih represent Mutran's appropriation of Shakespeare's song:

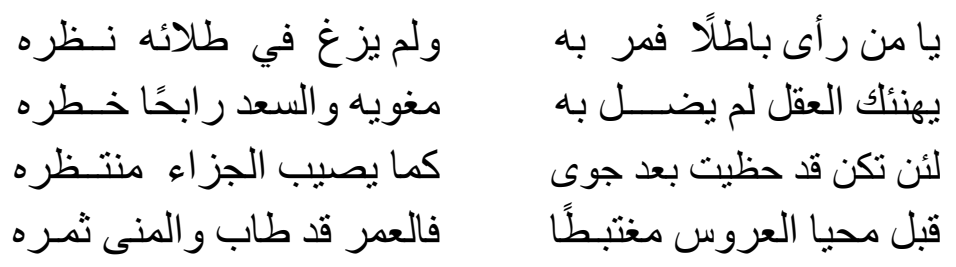


A detailed paraphrase of the English, and a rich commentary, may be found in a yet unfinished Ph.D. dissertation to be submitted by Israa Said to Fayoum University. Arabic readers can find for themselves how Mutran's version differs from Enani's and from the source text.

\section{Conclusion}

The examination of the Arabic translations of Shakespearean songs reveals that the early translators, brought up on classical Arabic models, have tended, more than modern verse translators, to appropriate Shakespeare's lines in their adaptations. It has also revealed that paraphrase, a canonical form of adaptation, would force the scholar to check it against the source text. Here too, translations in prose can be disappointing to the accuracy-seeker. Even if the prose translator is eager to produce an equivalent text, their adaptation will be lacking in aesthetic quality: as a paraphrase it will never be equal to the source text. The view of translation as adaptation has opened up new avenues for assessing translated poetry. 


\section{Works Cited}

1. Al-Wakeel, M., translator. The Merchant of Venice, in Arabic, 1992 (?1972)

2. Badawi, M.S., translator. King Lear, in Arabic, 2010.

3. Bassnett, Translation Studies, 2009.

4. Bevington, David, ed. Shakespeare's Works. $4^{\text {th }}$ Edition, updated, 1997.

5. Bevington, David, ed. The Merchant of Venice. Bantam, 1088.

6. Brown, John Russell, ed. The Merchant of Venice. Arden, 1964 (1972).

7. Drakakis, John, ed. The Merchant of Venice. Arden, 2010 (2018).

8. Enani, M. The Art of Translation, in Arabic, 1993.

9. Enani, M. The Translator's Guide, in Arabic, 2008.

10. Enani, M. translator. King Lear. In Arabic. GEBO, 1996.

11. Enani, M. translator. The Merchant of Venice. In Arabic. GEBO, 2002.

12. Foakes, R.A., ed. King Lear. Arden, 1997.

13. Halio, Jay L., ed. The Merchant of Venice. Oxford, 1993 (2008).

14. Hutcheon, Linda, with Siobhan O'Flynn. A Theory of Adaptation, 2006. ( $2^{\text {nd }}$ revised edn. 2016)

15. Kermode, Frank, ed. Shakespeare, King Lear: A Selection of Critical Essays, 1969.

16. Mahood, M.M., ed. The Merchant of Venice. Cambridge, 1987 (1992)

17. Mutran, Khalil, translator. The Merchant of Venice. In Arabic. 1998 (first edn. 1922)

18. Pooler, T., ed. The Merchant of Venice. Arden, 1916.

19. Sanders, Julie. Adaptation and Appropriation. Routledge, 2006.

20. Shelte \& Bassnett, eds., Theories of Translation, 1998.

21. Wilson, John Dover, ed. The Merchant of Venice. Cambridge, 1926. 